\title{
'Humanhood' in the Gospel of John
}

\begin{tabular}{|c|c|}
\hline $\begin{array}{l}\text { Author: } \\
\text { Johnson Thon }\end{array}$ & skutty $^{1,2}$ (1) \\
\hline $\begin{array}{l}\text { Affiliations: } \\
{ }^{1} \text { Department } \\
\text { Testament, Th } \\
\text { Theological Cc } \\
\text { Bengaluru, Inc }\end{array}$ & $\begin{array}{l}\text { of New } \\
\text { e United } \\
\text { ollege, } \\
\text { dia }\end{array}$ \\
\hline $\begin{array}{l}{ }^{2} \text { Department } \\
\text { Testament an } \\
\text { Literature, Fac } \\
\text { Theology and } \\
\text { University of } \\
\text { Pretoria, Sout }\end{array}$ & $\begin{array}{l}\text { of New } \\
\text { d Related } \\
\text { culty of } \\
\text { Religion, } \\
\text { retoria, } \\
\text { h Africa }\end{array}$ \\
\hline $\begin{array}{l}\text { Research Proj } \\
\text { Project Leade } \\
\text { Project Numb }\end{array}$ & $\begin{array}{l}\text { ect Registration: } \\
\text { r: E. van Eck (1) } \\
\text { er: } 2400030\end{array}$ \\
\hline $\begin{array}{l}\text { Description: } \\
\text { This research } \\
\text { research proje } \\
\text { 'Hermeneutic } \\
\text { directed by Pr } \\
\text { van Eck, Depa } \\
\text { Testament Stu } \\
\text { Related Litera } \\
\text { Theology and } \\
\text { University of }\end{array}$ & $\begin{array}{l}\text { s part of the } \\
\text { ct } \\
\text { s and Exegesis', } \\
\text { of. Dr Ernest } \\
\text { rtment of New } \\
\text { dies and } \\
\text { cure, Faculty of } \\
\text { Religion, } \\
\text { 'retoria. }\end{array}$ \\
\hline $\begin{array}{l}\text { Correspondin } \\
\text { Johnson Thon } \\
\text { jesusandjohns }\end{array}$ & $\begin{array}{l}\text { g author: } \\
\text { laskutty, } \\
\text { on@gmail.com }\end{array}$ \\
\hline $\begin{array}{l}\text { Dates: } \\
\text { Received: } 23 \\
\text { Accepted: } 20 \\
\text { Published: } 30\end{array}$ & $\begin{array}{l}\text { Mar. } 2021 \\
\text { May } 2021 \\
\text { July } 2021\end{array}$ \\
\hline $\begin{array}{l}\text { How to cite th } \\
\text { Thomaskutty, } \\
\text { '“Humanhood } \\
\text { of John', HTS } \\
\text { Studies/Theol } \\
77(4), \text { a6643. } \\
\text { org/10.4102/l }\end{array}$ & $\begin{array}{l}\text { is article: } \\
\text { J., 2021, } \\
\text { " in the Gospel } \\
\text { eologiese } \\
\text { gical Studies } \\
\text { https://doi. } \\
\text { ts.v77i4.6643 }\end{array}$ \\
\hline $\begin{array}{l}\text { Copyright: } \\
\text { C2021. The A } \\
\text { Licensee: AOS } \\
\text { is licensed un } \\
\text { Creative Comr } \\
\text { Attribution Lic }\end{array}$ & $\begin{array}{l}\text { uthors. } \\
\text { IS. This work } \\
\text { der the } \\
\text { nons } \\
\text { ense. }\end{array}$ \\
\hline Read online: & \\
\hline 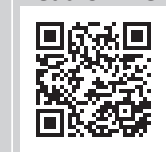 & $\begin{array}{l}\text { Scan this QR } \\
\text { code with your } \\
\text { smart phone or } \\
\text { mobile device } \\
\text { to read online. }\end{array}$ \\
\hline
\end{tabular}

This article is an attempt to explore the theme of 'humanhood' in the Fourth Gospel. The most important questions to be posed at the outset are the following: who is the model human presented in the gospel as per the Johannine community standards? How can a person acquire humanhood status according to the Johannine community? The divine and human interaction in the life and ministry of Jesus dynamically introduces the life ethics and mission aspects of the Johannine community. According to the Johannine community standards, people can achieve 'humanhood' status exclusively in relation to Jesus. As the community of John emphasises humanhood in relation to Jesus, a person can overcome all sorts of human-made boundaries, including the sexual, racial and class-oriented boundaries through the mediation of Jesus. This further means that the all-inclusive mission of Jesus foregrounds a new criterion for 'humanhood' in the Johannine community context. The article concludes by stating that the Johannine understanding of humanhood can be considered as a paradigm in the contemporary global scenario.

Contribution: This article contributes to the reader a wider hermeneutical framework and a new way forward in interpreting the gospel according to John by taking into consideration the humanhood aspects. As a theological and contextual interpretation of the Fourth Gospel, the article fits well within the scope of HTS Teologiese Studies/Theological Studies.

Keywords: humanhood; womanhood; Fourth Gospel; Johannine community; human culture; human boundaries.

\section{Introduction}

The Oxford Advanced Learner's Dictionary describes 'human' as 'a person rather than an animal or a machine'. A human is understood as someone 'subject to or indicative of the weaknesses, imperfections, and fragility associated with him or her'. In that sense, a human, on the one hand, is distinct from an animal or a machine and, on the other hand, is a figure of fragility. On the contrary, a human can demonstrate good values and virtues as per the demand of the time and space. This further means that humanhood is the state or character of being human. When we read the Fourth Gospel from a humanhood perspective, we attempt to see how the narrator of the gospel demonstrates the human values and virtues, such as goodness, kindness, hospitality, service, justice, righteousness and others, which are manifested through the protagonist Jesus and his interlocutors. We also attempt to see the way the antagonists of Jesus demonstrate the negative feelings in their speech and activities. The following are the four objectives of this article: firstly, to investigate the humanhood aspects of Jesus as a representative of the world 'from above'; secondly, to understand the implications of Jesus' humanhood in the Johannine community context; thirdly, to foreground the significance of the Sitz im Leben Jesu and the Sitz im Leben Kirche in the contemporary context; and fourthly, to consider the Johannine understanding of humanhood as a paradigm in the contemporary global scenario.

\section{Divine and human aspects of Jesus' character}

The narrative framework of John is within an inclusio between 1:1 (the Word was God) and 20:28 (Thomas' utterance: 'My Lord and my God', see Thomaskutty 2018:84). The elevated positions of the ' $U$ '-shaped plot at the beginning and end of the gospel foreground the divine nature of Jesus. The lowered position of the ' $U$ ' emphasises his human nature (Brant 2004:32-42). The preincarnate divine, the incarnate human and the post-incarnate divine natures are progressively narrated within the narrative framework of the gospel. During the pre-incarnate stage, Jesus was 'in the beginning' and was 'with God' (1:1; Moloney 1989/1998:34-35). His oneness with God and divine existence are at focus in 1:1-5 through the clause 'The Word was God'. The post-incarnate stage of Jesus, although not explicitly stated in John, is implicit in John as the narrator guides the readers through the proleptic expressions like the hour, the lifting up and the glorification of the Son 
of Man (Burge 1992:268-270). Jesus' life with the Father beyond the earthly canvas of the story, before and after the earthly ministry, reflects his heavenly connections. His divine nature is emphasised through the expressions such as 'he was with God in the beginning' (1:2) and 'through him all things were made' (1:3; Moloney 1989/1998:34-36).

As the co-creator of the universe with God, 'He [Jesus] came to that which was His own' (1:11a). The incarnate stage of Jesus is explicitly stated in 1:14:

The Word became flesh and made his dwelling among us. We have seen his glory, the glory of the one and only, who came from the Father, full of grace and truth. (Burge 1992:268-270)

Becoming flesh and dwelling amongst humanity enabled Jesus to adopt the human culture. Although Jesus adopted the human culture, he was reflecting the following aspects as a distinct and a paradigmatic human: his divine glory was visible; as the son of the heavenly Father, he was exclusively reflecting the heavenly glory; and he was full of grace and truth (1:14; Moloney 1989/1998:38-39). Although Jesus lived in total identification with the human beings, he reflected the heavenly virtues and attributes. This nature of Jesus' life in the world made him unique in status and power.

Although there is a sense of antagonism between the world from above and the world from below, Christ came as a mediator between the two worlds. As an agent of reconciliation between God and humanity, Jesus came to the world from below and accommodated its life situations (1:1:1-5, 14, Col 1:19-20; Heb 1:1-3; Teeple 1999:7-10). In that sense, Jesus' identity is placed between divinity and humanity. Jesus as the only begotten son of the heavenly Father (monogenēs, 1:18; 3:16) had to shift his Sitz im Leben from the heavenly world to the human culture. In his mission, Jesus exercised the following cultural realities: fusing the divine culture with the human, placing his role and status as a reconciler between the two cultural realities and propagating the heavenly culture in the Palestinian human context (Thompson 1992:376-377). Jesus' earthly mission can be considered as his transfer of role and status from the pre-incarnate and heavenly to the incarnate and human cultural realities (Johnson 1992b:481-484). In essence, Jesus came from the Sitz im Leben Gott, but he made himself part and parcel of the Sitz im Leben Welt. ${ }^{1}$ As a complete human, Jesus accommodated the earthly cultural patterns and, as a Jew, attuned himself to the Jewish ethos and pathos. As the story unfolds within the Palestinian topographical and geo-political canvas, the narrator delineates Jesus' identity as one amongst humanity (Schnackenburg 1965:1:265-273). That means, Jesus' identity in the world from below can be understood as his character as a human amongst other human beings.

The dwelling of Jesus with diverse people groups exemplifies how the Word tabernacled amongst humanity $(1: 39 b ; 2: 12$; $4: 40 ; 7: 1-9)$. His eating and drinking with people $(4: 7 ; 12: 1-8$; $13: 1-20 ; 19: 28 ; 21: 9-14)$ demonstrate his physical needs and human feelings. By walking with the disciples and the people at large, he modelled himself as a teacher. He called out disciples - Andrew, Peter, Philip, Nathanael (1:35-51) - to be with him and to carry out the heavenly message in the world (Brant 2011:48-54). By attending a wedding in Cana in Galilee and visiting the temple at Jerusalem, Jesus revealed his identity in the world and his social connections (2:1-11; 2:13-22; Brant 2011:55-59). These aspects show how he was part and parcel of the human culture. Without associating Jesus with the human culture, it is impossible to interpret the narrative annals of the gospel.

Jesus' conversation with Nicodemus develops in the form of a dialogue between a 'teacher from heaven' and a 'teacher of Israel' $(3: 2,10)$. As Nicodemus accepts Jesus as a 'Rabbi' and 'a teacher', a reader can understand his role and status in the world (Brant 2011:74-77). The Samaritan woman understands him as follows: 'How is it that you, a Jew, ask a drink of me, a woman of Samaria?' (4:9; Brant 2011:84). Whilst feeding the five thousand, Jesus understands the particular situation in life and behaves as per the needs and demands of the people (6:1-15; Witherington 1995:151-153). Jesus was aware of the Jewish customs and background $(4: 9 ; 6: 1 ; 11: 16,24 ; 18: 10,40$; $19: 13,17)$, attending the festivals $(2: 13,23 ; 4: 45 ; 5: 1 ; 6: 4 ; 7: 2$, $37 ; 10: 22 ; 11: 55-56 ; 12: 1,12,20 ; 13: 1,29 ; 18: 28,39)$ and transforming the society as an agent of liberation (Anderson 2014:142, 148). The public conversations of Jesus with his interlocutors resemble in several ways with that of the Platonic dialogues (Thomaskutty 2015:444-445). As a persuasive speaker, the rhetoric of Jesus was systematic and transformative as it was in the case of Socrates, Gautama Buddha and Sri Ramakrishna (Wenley 2002:1-9, 170-190). Jesus identified with and adopted a large number of worldly patterns, customs and idioms.

The usage of the family metaphor - God as the Father, Jesus as the Son, Holy Spirit as the comforter, and believers as the children - provides the reader a worldly canvas to understand the divine mission in the world (Van der Watt 2000:161-392). Jesus appears as a family friend of Lazarus (11:3, 11), a companion of Mary and Martha who weeps at the tomb (11:35) and a teacher who washes the feet of his disciples (13:1-20; Kanagaraj 2005:356-357, 360, 370-371, 429-444). As it was in the case of Socrates, Jesus delivers a Farewell Discourse (chaps. 13-17) and later on he was arrested, tried, crucified and put to death (Talbert 2005:207-209). ${ }^{2}$ All these narrative aspects take our attention to Jesus' accommodative role in the world. His accommodation of the worldly culture as the incarnated Logos exemplifies his 'in between' position and his role and status as a heavenly messenger in the world. In the narrative annals of John, Jesus demonstrates himself as the ideal human amongst the misunderstanding and unknowing people.

The narration in 2:23-25 demonstrates Jesus' humanhood in the world with several layers of meaning: firstly, Jesus was attending the Passover festival as one amongst a large number 2.See http://www.worldfuturefund.org/Reports/Socrates/socrates.html, accessed on 10 October 2020. 
of people, but unlike others he was able to perform miraculous signs because of his divine nature; secondly, although he was counted as one amongst many, people believed in him because of his signs; thirdly, Jesus did not entrust himself to the human beings of the world because he was a perfect human and knew the shortcomings of other human beings; fourthly, as a heavenly human, he was able to understand the earthly humans even without their testimonies; and fifthly, as the Son of God, he was able to know 'what was in a man [human being]' (Moloney 1989/1998:84-87). The passage amply demonstrates the dichotomy between the 'heavenly human' and the 'earthly human'. Jesus' identity is demonstrated as a superior human as he was attuned to the heavenly realities whilst living in the world below. Jesus appeared in human form to transform people and to enable them to follow the virtues and values of the heavenly kingdom. Thus, the heavenly Jesus became earthly in order to transform the world (Anderson 2011:26-27). As earthly and heavenly are part and parcel of Jesus' identity, his mission was all about making the human beings both earthly and heavenly. Jesus is the perfect model of humanhood that fuses both the earthly and the heavenly. In his ministry, Jesus emphasised the same to his disciples and followers.

\section{The concept of humanhood}

As stated above, Johannine humanhood can be understood only in terms of a fusion between the heavenly and the earthly. On the basis of the purpose statement of the gospel, a reader can perceive the humanhood concerns of the Johannine community as follows: firstly, believing that Jesus, the Christ, the Son of God, is one of the significant requirements; and, secondly, through believing, people should ensure that they can acquire life in his name (20:31; Kanagaraj 2005:664-666). This fusion of heavenly and earthly makes people enjoy the divine blessings in this world (Kanagaraj 2005:664-666).

In the call narratives, earthly beings are coming in tune with the heavenly: firstly, Andrew declares that 'We have found the Messiah' (1:41); secondly, Simon Peter was commended by Jesus as the 'Cephas' (1:42); thirdly, Philip understood him as 'one Moses wrote about in the Law, and about whom the prophets also wrote - Jesus of Nazareth, the son of Joseph' (1:45); and fourthly, Nathanael recognised him as 'Rabbi', 'Son of God' and 'King of Israel' (1:49; Moloney 1989/1998:54-62). The call narratives amply demonstrate that how people identified Jesus through their faith reactions and fused their earthly life in relation to the heavenly realities. This recognition in relation to Jesus transformed them to the community expectations of humanhood. Their humanhood is acknowledged on the basis of their new identity in Christ, acceptance from the side of Jesus, and believing and following the pre-existent and incarnate Logos (Anderson 2011:26-27).

The new joy Jesus shares in the wedding place in Cana enables people to experience the joy of eschatological salvation (2:1-12). As Jesus initiates to establish the new temple, he invites people to be part of the new age of worship (2:13-22).
Whilst the Cana incident implies the Messianic Banquet, the temple cleansing incident attunes our attention toward the eschatological worship. Johannine humanhood, as a fusion between the divine and the human, is reflective of the salvific fellowship and spiritual worship amongst the people (Thomaskutty 2015:78-86). As Jesus is the harbinger of the spiritual fellowship and worship, people cannot experience humanhood without Jesus. In an honour and shame context, Jesus resolves the deficiency of wine and joy in a wedding place. From a shameful situation, Jesus brings the family to an honourable position. In the temple at Jerusalem, Jesus drove all those who occupy the gentile court and the women court (Thomaskutty 2015:93-106). Whilst the family members are brought to the honourable humanhood in 2:1-12, the gentile and women devotees are brought to humanhood in 2:13-22. Both of the incidents in chapter 2 demonstrate the way humanhood was sustained in relation to Jesus.

Although a Pharisee and a member of the Jewish ruling council, Nicodemus was not recognised as a virtuous human by Jesus. Jesus' dialogue turned to monologue in 3:1-21 is a call to believing in Jesus, following him, and being spiritual. Nicodemus' humanhood is revealed in a round shape as he seeks Jesus (3:1-10), taking side with him (7:50-52), and silently following him (19:38-42). The conversation between Jesus and the Samaritan woman in 4:1-42 delineates the way the woman was denied the rights of humanhood in the society as she was considered a woman, a Samaritan, and a morally weighed down personality (Thomaskutty 2019:79-100). Jesus invites her to drink from the well of God (4:10, 13-14), a new worship in Spirit and in Truth (4:21-24), and the eternal life experience $(4: 14,36$; Thomaskutty 2017a:64-68). He transforms her from her shameful past to a new identity in Christ. She is elevated from the human-less situation to humanhood.

The invalid person (5:1-18) is identified as one who was in quarantine during a prolonged period (38 years; 5:5), a person without any human assistance (5:7a) and one who was always in frustration (5:7b). Jesus brings his life situation to humanhood although he was formerly considered as a diseased and a sinful person (5:1-6, 14; Thomaskutty 2015:181-205). Similarly, the man born blind was considered a diseased (9:1-2), sinful $(9: 2,34)$ and human-less figure. Jesus elevates his position from the disgraceful past to the status of believing and humanhood (Thomaskutty 2015:310-340). In 13:1-20, Jesus shows servant-leadership as a method to demonstrate humanhood in the world (Moloney 1987/1998:370-381). He invites his disciples to be servantleaders as they represent the world from above, following the path of Jesus, and believing in him.

As the 'I AM' (6:48; 8:12/9:5; 10:7; 10:11; 11:25; 14:6; 15:1), Jesus reveals his true identity as the heavenly human in closer relationship with the earthly realities. When Jesus says 'you are my friends if you do what I command' (15:14), he reveals that his model of friendship restores humanness and instructs that humanhood can be restored only in relationship 
with the creator (cf. 1:3-4; Moloney 1987/1998:424-425). The above details give us insights concerning the humanhood in the following ways: firstly, as Jesus is the true human, conceptualisation of humanhood is possible exclusively in relation to his person and work; secondly, being in Jesus (15:1-5; 17:1-26), following and believing in him, and doing the will of the Father enable people to achieve humanhood; thirdly, Jesus as the agent of liberation can transform humanless to humanhood; and, fourthly, as Jesus is involved in the creation of humanity and the created order, humanhood can be achieved only in relational terms.

\section{Womanhood as humanhood}

Johannine women show devotion towards Jesus and affirm their faith with profundity than some of their male counterparts (Beirne 2003:1-41). As part of the community of John, they seemingly enjoyed considerable freedom in matters of exercising their spirituality, expressing views openly at the public places and developing faith in Jesus as a powerful means to come out of their parochial worldviews (Witherington 1988:175-182). Jesus' position as the protagonist of the story and Johannine community's reinterpretation of the events from the Sitz im Leben Jesu to address the existential struggles of the Sitz im Leben Kirche enable the narrator to sustain some of the values and virtues of the Jesus movement. ${ }^{3}$ The women characters of John attain humanhood through their relationship with Jesus.

John sustains women's representation from varied levels of life situations: Jesus' mother appears both in the context of a celebrative mood $(2: 1-5)$ and in a lamenting situation (19:25-27); the unnamed woman appears at a public well in the Samaritan context (4:1-42); Martha and Mary appear both in a bereaving situation $(11: 1-44)$ as well as in a context in which they show superabundant generosity (12:1-8); and Mary Magdalene is in a lamenting attitude at the tomb of Jesus and later on as a proclaimer of the resurrected Jesus (20:1-2 and vv. 11-18; Witherington 1988:175-182). The above indications reveal that Johannine women exercised their faith at both private and public sectors of life. Their representation from varied walks within the life situation of Jesus and the reinterpretation of those kernels into the life situation of the Johannine community reveals their openness even in the case of women's status and role (Thomaskutty 2020:141). ${ }^{4}$ This aspect of the Johannine narrative with women characters on par with the male characters and in closer affinity with Jesus foregrounds their humanhood (Martyn 1968:24-151; Thomaskutty 2020:158). In a context in which women were treated with lower esteem, Johannine caricature of women with higher esteem is a paradigm.

John presents Jesus as one who empowers women and sets their belief against the unfaithfulness of men (Kanagaraj

3.These expressions mean, the life situation of Jesus and the life situation(s) of the early Christian community(ies). See Marxen (1959/1969).

4.John the narrator captures the story of Jesus as the protagonist in order to re-tell and re-interpret that with greater efficacy.
2001:60-61). The following roles of Johannine women are influential: Mary the mother of Jesus was playing significant roles during the wedding banquet and near the cross (2:1-12; 19:25-27); the woman at the well was instrumental in bringing the gospel to her own people (4:1-26, 39-42); Martha and Mary were believing and ministering to Jesus in Bethany (11:1-45; 12:1-8); and Mary Magdalene was sharing the good news of Jesus' resurrection with her male counterparts (19:25; 20:1-2, 11-18; Thomaskutty 2020:62). Johannine women were agents of radical transformation in their respective areas of life (Chakkuvarackal 2002:88). The Samaritan woman had an encounter with Jesus and that resulted into her experience of acquiring greater knowledge. This unique experience enabled her to lead her people towards the 'truly Saviour of the world' (4:39-42; Thomaskutty 2020:173-189). The Samaritan woman's involvements can be introduced as a paradigm to transform people from misunderstanding situations to greater understanding, awareness about the 'past' to a transformative living in the 'present', and emphasising the older traditions to life affirming newer experiences. Martha and Mary of Bethany can be followed as models to shift away from future-oriented eschatological hopes to presentaffirming and living experiences (Thomaskutty 2020:173189). The sisters' positive qualities such as hospitality, generosity and devotion to Christ are to be exercised for transformative living in all contexts.

Mary Magdalene outsmarts her male counterparts as she was exemplifying her devotion to Jesus through both proclamations and actions. As she was demonstrating her profoundest proclamation, keeping up fellowship with the community of God, and involving dynamically around and beyond the tomb of Jesus, her character can be hailed as a model for women in the oppressive socio-religious structures. Just as these Johannine women exemplified their leadership roles, devotion to Jesus, progress in understanding Jesus, and witnessing Christ to diverse walks of life, women at varied life situations can demonstrate their intrinsic qualities to transform themselves and the society (Thomaskutty 2020:173-189).

The above analysis enables us to see how the women of John's Gospel appear in relation to Jesus and other characters of the macro-story. Although they were considered as powerless in their own socio-religious and politico-cultural contexts, they assume power both within the Sitz im Leben Jesu and within the Sitz im Leben Kirche. We observed that as part of the Johannine community, women of John enjoyed considerable freedom. Mary the mother of Jesus demonstrates her leadership quality at the wedding in Cana and her deep devotion to Jesus near the cross (Thomaskutty 2017b:62). Although the woman at the well was misunderstanding in nature and parochial in perception, her progress in realising the prophet-Messiah and guiding Samaritans towards the 'truly Saviour of the world' is persuasive (Bennema 2009:86-93). Martha and Mary of Bethany show their family confession that if Jesus was with them, Lazarus would not have died. They develop their faith and devotion in Jesus. Whilst Martha develops from her 
future-oriented eschatological hope to the present-oriented realisation of the Messianic Age, Mary demonstrates her identity through her superabundant generosity (Bennema 2009:145-156). All these characteristics of the women characters reveal their humanhood both in the Jesus Movement and in the Johannine community context.

Mary Magdalene's speeches and actions reveal the fact that she was a paradigmatic personality for the early Christian communities including the male characters of the story. Her personal proclamation (i.e. 'I have seen the Lord') later on became the community proclamation (i.e. 'We have seen the Lord'; Bennema 2009:196-201). In their encounter with Jesus, all these women showed their love and devotion to their Lord. All of them used their intrinsic 'woman-power' to come out of their narrow confines of life. As Jesus liberated women from the confines of social, religious, geographical, moral and sexual barriers, and the women of John are living examples of such a movement, the readers of the Fourth Gospel understand that womanhood was transformed as humanhood in the Johannine narrative artistry.

The above details about women identity in the Jesus Movement and in the Johannine community foreground certain realities: firstly, the Jesus Movement was genderinclusive where men and women enjoyed considerable freedom and exemplified their humanhood with a positive outlook; secondly, Johannine women characters like the mother of Jesus, the Samaritan woman, Martha and Mary of Bethany, and Mary Magdalene are foregrounded as complete human beings over against the existent socio-religious and politico-cultural contextual understanding of humanhood; thirdly, Johannine concept of humanhood can be considered as transformed livelihood rather than restricted and genderbased narrow mindedness; fourthly, men and women are put side by side in the Johannine narrative framework in order to demonstrate the Johannine ideology of humanhood as transformed living together; and fifthly, Johannine women are introduced as key humans as they function as instrumental characters to introduce the 'truly Saviour of the world' and to act as 'apostle to the apostles'. These understandings about the Johannine women demonstrate the way womanhood was portrayed as humanhood in the Fourth Gospel.

\section{Humanhood in the Johannine community}

The narrative framework of John reflects a two-level drama. On the one hand, it is the story of Jesus, and on the other hand, it is the story of the early Johannine community (see Martyn 1968). As the children of light, the community of John was enjoying the divine blessings in the world irrespective of their continuous struggles and minority status. On the contrary, the Jewish community was considered as sons of darkness irrespective of their powerful and majoritarian status. In a patron-client social context in which one's honour or shame was determined on the basis of several factors, people had to strive hard to usurp the superiority status over against the prevailing inferiorities. It was in such a context that the Christian communities, especially the Johannine community as an emerging group, had to undergo constant existential struggles. But, the community's inclination to Jesus and the axioms of God enabled them to achieve a new status. As per the Johannine language, through believing in Jesus they achieved the status of humanhood. The protagonist and antagonist rivalry between the sons and daughters of light and sons and daughters of darkness brought a friction between the Jewish authorities and the Johannine community (Shirbroun 1992:472-473). In that process, as followers and believers of Jesus, the Johannine community achieved the status of humanhood and the Jewish antagonists lost the human attributes. As the antagonists of Jesus, the Jewish authorities lost the status of the children of God and thus fell short of the glory and likeness of Jesus.

The Jews are presented in the gospel as hostile to Jesus and all those who confess that he is the Christ (cf. 9:22; 12:42; 16:2). Their antagonistic trends are widespread in the narrative framework of the Fourth Gospel on multifarious intervals (cf. 11:45-53; 18:28-19:16; 19:17-22; 20:19). Moloney $(1987 / 1998)$ says that:

The conflict between Jesus and the 'Jews' are more the reflection of a Christological debate at the end of the first century than a record of encounters between Jesus and his fellow Israelites in the thirties of that century. (p. 10)

Thus, John's typical vantage point enables him to realign the story of Jesus within the narrative framework of the story of the Johannine community (Martyn 1968:1-20). The Jews show their antagonistic attitudes through the following activities: they 'try to kill' the Saviour of the world $(7: 19,25)$; call him 'demon-possessed' $(7: 20 ; 8: 48,52 ; 10: 20)$ and a 'raving mad' (10:20); 'tried to seize him' (7:30, 44; 10:39); 'sent temple guards to arrest him' (7:32); call him a 'Samaritan' and an illegitimate one (8:48); 'picked up stones to stone at him' (8:59; 10:31); and call him a 'blasphemer' (10:33; Thomaskutty 2020:153-171). Their antagonistic attitudes towards Jesus reveal their non-human tendencies. The Jews, as they do not follow Jesus, are counted as 'those who walk in darkness' (8:12). Although they claim that they see, Jesus considers them as blind people $(9: 39,41)$. As believing and following Jesus are considered as the hallmarks of humanhood, the Johannine community enjoyed the privileges of humanhood in the world. On the other hand, the Jewish authorities, although the citizens of the world, were not counted as humans in the real sense (Thomaskutty 2020:153-171).

This aspect of the human and non-human dualism is at the centre of Johannine narrative framework. On the one hand, the elites (i.e. the Jewish authorities) are not considered as people with humanhood status, and on the other hand, the marginal community (i.e. the Johannine community) is considered as people in humanhood status through their faith in Jesus. This aspect introduces a macro-irony within the Johannine narrative framework. Those who achieved humanhood are the called ones (Andrew, Peter, Philip, 
Nathanael, and others; chap. 1): the mother of Jesus who stood with him from beginning till end $(2: 1-12 ; 19: 25-30)$, Nicodemus who secretly followed Jesus (3:1-10; 7:50-52; 19:38-42), a Samaritan woman who was religiously, racially and morally an alien and her villagers (4:1-42), a royal man who was most possibly a gentile (4:46-54), an invalid person who was both diseased and sinful (5:1-18), the followers who believed him (6:66-71), a man born blind who was socially and religiously a neglected figure (9:1-41), the family of Mary, Martha and Lazarus in Bethany who loved Jesus and devoted themselves to him $(11: 1-44 ; 12: 1-8)$, the Greeks who came to see Jesus (12:20-22), those who inclined to Jesus during the private discourse and ministry (chaps. 13-17), Joseph of Arimathea (19:38-42), Mary Magdalene who was foregrounded as an apostle to the apostles (19:25; 20:1-18), the disciples who declared that 'we have seen the Lord' (20:19-25), Thomas who stated that Jesus is 'My Lord and my God' (20:28) and the Beloved Disciple who appears as the ideal disciple $(13: 23 ; 19: 26-27 ; 20: 2 ; 21: 7,20-23) .{ }^{5}$ As per the Johannine community understanding, the above-mentioned are some of the people that received humanhood in its real sense.

The framework of John is gnomic and universalistic as the gospel idealises humanhood in relationship with Jesus. The Jewish authorities with their nationalistic and Mosaic understanding claimed that they are the real citizens of the land and that they possess the expected humanhood (Thomaskutty 2017a:64-68). But, as per the Johannine community standard, the Jewish authorities are the fallen humanity because of their rejection of the creator of the universe. The Johannine community standard makes it a point that humanhood can be achieved through Christ irrespective of caste, colour, gender, race, moral and religious backgrounds, and nationalistic boundaries. Whilst the Jewish standard of humanhood is nationalistic and exclusive, the Johannine community implemented a universalistic and inclusive standard for achieving humanhood (Thomaskutty 2017a:64-68).

Jesus transforms human culture in a divine way. The purpose of his coming was to redeem the world and to attune it in harmony with the from above realities. A divine-and-human harmony in particular and a divine-and-world reconciliation in general were the ultimate concerns of Jesus' mission. John's realised eschatological framework describes the world from below in vertical interaction with the world from above (Johnson 1992:469-471). This vertical, realised and constant relationship between the earthly and the heavenly is the expected goal of his mission in the world (Johnson 1992:469-471). The holistic transformation intended through the mission and ministry of Jesus is foregrounded in the Fourth Gospel with clarity. The cultural and social phenomena of the world were deviated from the divine plan and hence Jesus was sent as the agent of God to fulfil the heavenly mission. In Jesus' missional paradigm, his ultimate concern was making human beings human and ultimately leading them to the status of humanhood.

5.For more details, see Bennema (2009), Encountering Jesus: Character Studies in the Gospel of John.
The Johannine community was a transformed community through their faith in Jesus and they were rooted in the love of God. John's narrative framework gives the reader convincing clues about the transformation of various walks of people: the common fisher folk (the disciples; Thomaskutty 2020:58-78), the women-folk (the mother of Jesus, the Samaritan woman, Mary and Martha, and Mary Magdalene; Thomaskutty 2020:173-190), the differently abled (the invalid person and the man born blind), the communities that followed him (on various occasions), the Greeks (12:20-22; Thomaskutty 2015:169-180, 310-340). The above details enable us to understand the role and status of Jesus as a transformer of the earthly culture based on heavenly principles. Human beings received their true humanhood through their relationship with Jesus who is the creator of the universe (1:3-5).

\section{Humanhood in the contemporary context}

In the above sections, we attempted to understand the aspect of humanhood in Jesus Movement and in the Johannine community context with evidences from the Scripture. We explored several aspects of the Jesus Movement and the Johannine community experiences to arrive at certain conclusions. The Sitz im Leben Jesu and the Sitz im Leben Kirche aspects were considered to delineate Christ and his dynamic relationship with the world. As Jesus introduces the heavenly principles in the earthly setting, he emphasises the aspects of the eternal life. As Jesus offers the gift of abundant life, people who are marginalised and dehumanised receive a new hope and identity in the world. As the Word became flesh, Jesus accommodates the worldly culture to convey the heavenly message. He fuses the from above message with the earthly to transform the world. In that sense, the Johannine community followed a rhetoric of distinction as an alternative culture (Carter 2008:14, 15, 20). In that process, the real humanhood is understood in terms of relationship with God and the Word.

In the world, Christ functions in relation to the cultural phenomenon in multifarious ways: firstly, Christ exercises the heavenly power and authority over against the from below culture when it goes wrong; secondly, he accommodates the worldly culture to communicate the message of eternal life in its own idiom and the patterns of the culture below; thirdly, he functions above the worldly culture as he responds to the sinful nature of the world, attunes the earthly with the heavenly realities, and exists as the ideal for the world to follow; fourthly, he remains paradoxical to the human culture as the sinless and sinful, light and darkness, and truth and untruth cannot coalesce; and fifthly, he transforms the human culture as God of heavens coming to the world as the creator of the universe. By introducing a new identity and humanhood principle in the world, Christ invites the attention of the world from below towards a life-affirming, liberative and heavenly humanhood.

In the process of interpreting the text, the existential realities of the suffering people, both in the church and in the society, 
should be merged to the life-setting of Jesus and the Johannine community. This dynamic interlocking of multiple texts shall help the interpreter to derive theological and contextual implications in new idiom. The God of the Bible reveals himself or herself through the creation and the full revelation in the person and work of Jesus Christ. Jesus appears as co-creator with God, the Son of God who suffers for humanity, and the resurrected Lord and the Saviour of the world. The transforming power of Christ can liberate the Indian culture and the society from the clutches of rich and poor dichotomy, Dalit, Tribal and Adivasi struggles, racist treatments, marginalisation of women, and various other human-made and culture-bound taboos in the contemporary context. An interpreter of the text can consider the existential realities of people and offer a new humanhood model that is undercurrent and obvious within the Fourth Gospel. The Fourth Gospel can be considered as a paradigm in the contemporary global context where human beings are in struggle because of the pandemic of the coronavirus disease 2019 (COVID-19) in order to attribute real humanhood and identity. As the Johannine community conceptualised, real humanhood can be actualised only in relationship with Jesus.

\section{Conclusion}

In recapitulation, humanhood in John's gospel can be conceptualised in the following ways: firstly, Christcentred humanhood is the real mode of human identity; secondly, being antagonistic to Jesus and rejecting the way of God are signs of inhuman life in the world; thirdly, humanhood can be experienced when people fuse their identity and existence in relationship with the world from above; fourthly, real humanhood can be achieved irrespective of people's varied backgrounds and identities in the world; and fifthly, 'believing', 'following' and 'worshipping' are some of the significant characteristics to achieve humanhood in the world. As the Johannine community (Sitz im Leben Kirche) was aligning its pathos within the life situation of Jesus (Sitz im Leben Jesu) in order to make the humanhood aspects obvious, the contemporary church can realign its shameful, minoritarian, persecuted and dehumanised status within the life situations of the Jesus Movement and the Johannine community realities to foreground its identity and humanhood in a dynamic and interlocking way. This new identity and humanhood of the people of God can function as a paradigm in the contemporary context. The open-minded and inclusive paradigm of the Johannine humanhood through the mediation of Christ can be modelled as a new way forward in our missional and ministerial involvements in the world.

\section{Acknowledgements Competing interests}

The author declares that he has no financial or personal relationships that may have inappropriately influenced him in writing this article.

\section{Author's contributions}

J.T. is the sole author of this research article.

\section{Ethical considerations}

This article follows all ethical standards for research without direct contact with human or animal subjects.

\section{Funding information}

This research did not receive any specific grant from any funding agency in the public, commercial or not-for-profit sectors.

\section{Data availability}

No data sharing is applicable to this article as no new data were created or analysed in this study.

\section{Disclaimer}

The views and opinions expressed in this article are those of the author and do not necessarily reflect the official policy or position of any affiliated agency of the author.

\section{References}

Anderson, P.N., 2011, The riddles of the Fourth Gospel: An introduction to John, Fortress Press, Minneapolis, MN.

Anderson, P.N., 2014, From crisis to Christ: A contextual introduction to the New Testament, Abingdon Press, Nashville, TN.

Beirne, M.M., 2003, Women and men in the Fourth Gospel: A genuine discipleship of equals, Journal for the Study of the New Testament Supplement Series 242, Sheffield Academic Press, London.

Bennema, C., 2009, Encountering Jesus: Character studies in the Gospel of John, Primalogue, Bangalore.

Brant, J.A., 2004, Dialogue and drama: Elements of Greek tragedy in the Fourth Gospel, Hendrickson, Peabody, MA.

Brant, J.A., 2011, John, Paideia commentaries on the New Testament, Baker Academic, Grand Rapids, MI.

Burge, G.M., 1992, 'Glory', in Dictionary of Jesus and the Gospels, pp. 268-270, InterVarsity Press, Downers Grove, IL.

Carter, W., 2008, John and empire: Initial explorations, T \& T Clark, London.

Chakkuvarackal, J., 2002, "Glimpses of the "feminine" in the Indian religion and society', Indian Journal of Theology 44(1-2), 79-93.

Johnson, D.H., 1992a, 'Life', in Dictionary of Jesus and the Gospels, pp. 469-471, InterVarsity Press, Downers Grove, IL.

Johnson, D.H., 1992b, 'Logos', in Dictionary of Jesus and the Gospels, pp. 481-484, InterVarsity Press, Downers Grove, IL.

Kanagaraj, J.J., 2001, 'The profiles of women in John: House-bound or Christ-bound', Bangalore Theological Forum 33(2).

Kanagaraj, J.J., 2005, The Gospel of John: A commentary, Operation Mobilization Books, Secunderabad.

Martyn, J.L., 1968, History and theology in the Fourth Gospel, Abingdon, Nashville, TN. Marxen, W., 1959/1969, Der Evangelist Markus, Vandenhoeck \& Ruprecht, Germany.

Moloney, F.J., 1987/1998, Sacra Pagina: The Gospel of John, The Liturgical Press, Collegeville, PA.

Schnackenburg, R., 1965, The Gospel according to St. John, transl. K. Smyth, Herder and Herder, New York, NY.

Shirbroun, G.F., 1992, 'Light', in Dictionary of Jesus and the Gospels, pp. 472-473, InterVarsity Press, Downers Grove, IL.

Talbert, C., 2005, Reading John: A literary and theological commentary on the Fourth Gospel and the Johannine epistles, Smyth \& Helwys Publishing, Macon, GA.

Teeple, H.M., 1999, 'Qumran and the origin of the Fourth Gospel', in D.E. Orton (ed.), The Composition of John's Gospel: Selected studies from Novum Testamentum, pp. 1-20, Brill, Leiden.

Thomaskutty, J., 2015, Dialogue in the book of signs: A polyvalent analysis of John 1:19-12:50, Biblical Interpretation Series 136, E. J. Brill, Leiden. 
Thomaskutty, J., 2017a, 'Biblical interpretation in the Global-Indian context', Fuller Magazine, Issue 8, 64-68.

Thomaskutty, J., 2017b, 'Reading John's Gospel in the Bangladeshi context', Journal of Asian Evangelical Theology 21(1-2), 53-72.

Thomaskutty, J., 2018, Saint Thomas the Apostle: New Testament, Apocrypha, and historical traditions, Bloomsbury T \& T Clark, London.

Thomaskutty, J., 2019, 'Johannine women as paradigms in the Indian context', in Acto Theologica Supplementum 27, pp. 79-100, University of the Free State, Bloemfontein.

Thomaskutty, J., 2020, The Gospel of John: A universalistic reading, Christian World Imprints, Delhi.
Thompson, M.M., 1992, 'John, Gospel of', in Dictionary of Jesus and the Gospels, pp. 368-383, InterVarsity Press, Downers Grove, IL.

Van der Watt, J.G., 2000, Family of the King: Dynamics of metaphor in the Gospel according to John, BINS 17, E. J. Brill, Leiden.

Wenley, R.M., 2002, Socrates and Christ: A study in the philosophy of religion, Cambridge Scholars Press, Adelaide.

Witherington, B., 1995, John's wisdom: A commentary on the Fourth Gospel, Westminster John Knox Press, Louisville, KY.

Witherington, B., 1988, Women in the earliest churches, Cambridge University Press, Cambridge. 